\title{
Isolasi Senyawa Rubrasanton dan Parvifolisanton C dari Ekstrak Kulit Batang Garcinia tetrandra Pierre
}

\author{
Rizaldy Nizzah Kurniawan dan Taslim Ersam \\ Departemen Kimia, Fakultas Ilmu Alam, Institut Teknologi Sepuluh Nopember (ITS) \\ e-mail: beckers@chem.its.ac.id
}

\begin{abstract}
Abstrak-Spesies Garcinia tetrandra Pierre adalah salah satu spesies dari keluarga besar Cluciaceae yang telah dikenal mengandung turunan senyawa santon terprenilasi. Dua senyawa turunan santon berhasil didapatkan dari ekstrak diklorometana kulit batang Garcinia tetrandra yaitu rubrasanton (1) dan parvifolisanton $C$ (2). Isolasi dua senyawa tersebut menggunakan metode ekstraksi secara maserasi, fraksinasi menggunakan berbagai metode kromatografi (kromatografi cair vakum dan kromatografi radial) dan pemurnian menggunakan rekristalisasi dua pelarut. Penentuan struktur senyawa tersebut berdasarkan analisis spektroskopi IR, UV, ${ }^{1} \mathrm{H}-\mathrm{NMR}$ dan ${ }^{13} \mathrm{C}$-NMR.
\end{abstract}

Kata Kunci-Garcinia tetrandra Pierre,Santon.

\section{PENDAHULUAN}

$\mathrm{D}$ belahan dunia ini diperkirakan terdapat 250.000 spesies tumbuhan tingkat tinggi sedangkan 30.000 spesies lainnya terdapat di Indonesia. Indonesia merupakan negara kepulauan yang memiliki iklim tropis setiap tahun sehingga terdapat berbagai macam ekosistem. Oleh karena itu, negara Indonesia disebut sebagai megabiodiversitas [1]. Salah satu tumbuhan tingkat tinggi Indonesia yang berpotensi sebagai bahan kimia hayati bioaktif adalah tumbuh-tumbuhan yang termasuk famili Clusiaceae yang di masyarakat dikenal sebagai keluarga manggis. Taksa memiliki 40 genus dan 1000 spesies tersebar di daerah tropis dan sub-tropis, yang terdiri dari 4 genus utama yaitu Chalophyllum, Mesua, Garcinia dan Mammea [2].

Garcinia merupakan sumber senyawa-senyawa turunan fenolat dari golongan santon, kumarin dan benzofenon yang memiliki beraneka ragam bioaktifitas [3]. Salah satu spesies dari genus Gacinia penghasil senyawa-senyawa kimia santon adalah Garcinia tetrandra Pierre, atau di masyarakat lebih dikenal dengan nama wadung. Tumbuhan ini banyak tersebar di daerah Indonesia Timur dan merupakan koleksi Taman Nasional Meru Betiri, Jember. Berdasarkan penelitian sebelumnya, tumbuhan ini dikenal menghasilkan senyawa-senyawa santon terprenilasi dan memiliki sifat aktifitas sebagai antioksidan, antibakteri, antimikroba dan antimalaria. Beberapa senyawa santon telah berhasil diisolasi dari G. tetrandra Pierre oleh peneliti-peneliti sebelumnya seperti pada bagian kulit akar yaitu 1,6dihidroksi-7-metoksi-8-prenil-(3,4)-kromanosanton [4], kayu akar yaitu Dulsanton D [5] dan kulit batang yaitu 3isomangostin [6].

Apabila ditinjau dari jalur biogenesisnya, masih terdapat peluang ditemukannya senyawa-senyawa baru dalam isolasi Garcinia tetrandra Pierre. Selain itu, perbedaan spesies dan lingkungan dapat menjadi salah satu faktor yang menyebabkan perbedaan senyawa yang dihasilkan pada isolasi suatu tumbuhan. Oleh karena itu, perlu dilakukan penelitian lebih lanjut tentang isolasi senyawa metabolit sekunder khususnya senyawa santon dari tumbuhan Garcinia tetrandra Pierre dan uji bioaktivitas senyawa yang diperoleh.

Pada penelitian ini dilakukan isolasi dan identifikasi senyawa turunan santon dari ekstrak diklorometana kulit batang Garcinia tetrandra Pierre dengan menggunakan metode ekstraksi secara maserasi, fraksinasi menggunakan berbagai metode kromatografi (kromatografi cair vakum dan kromatografi radial) dan pemurnian menggunakan rekristalisasi dua pelarut.

\section{URAIAN PENELITIAN}

\section{A. Alat dan Bahan}

Alat yang diperlukan dalam percobaan ini adalah rotari evaporator vakum (BUCHI), gelas ukur, pipet tetes, pengaduk kaca, kaca arloji, pinset, pipa kapiler, botol vial, peralatan kromatografi cair vakum (KCV), chamber kromatografi lapis tipis preparatif (KLTp), seperangkat alat uji titik leleh Fisher-John, spektrometri UV (Shimadzu) pada panjang gelombang 200-600 nm, spektrometer FTIR (Shimadzu) dengan metode pelet KBR pada daerah 4000$400 \mathrm{~cm}^{-1}$, seperangkat alat kromatografi lapis tipis (KLT), kromatotron, lampu UV dengan panjang gelombang $254 \mathrm{~nm}$ dan $366 \mathrm{~nm}$ dan spektrometer NMR Bruker 400 AVANCE (400 MHz untuk ${ }^{1} \mathrm{H}-\mathrm{NMR}$ dan $400 \mathrm{MHz}$ untuk ${ }^{13} \mathrm{C}-\mathrm{NMR}$ ).

Bahan yang digunakan dalam percobaan ini adalah kulit batang dari $G$. tetrandra Pierre sebanyak $4 \mathrm{~kg}$ yang didapatkan dari Taman Nasional Meru Betiri, Jember, Jawa Timur dan telah diidentifikasi di Kebun Raya Purwodadi dengan nomor spesimen XVII.J.11.22, sillika gel $60 \mathrm{G}$ untuk kromatografi kolom, alumunium sheets $20 \times 20 \mathrm{~cm}$ silika gel 60 F254 merck untuk kromatografi lapis tipis (KLT), Sephadex ${ }^{\text {TM }}$ LH-20, silika gel 60 (70-230 mesh) untuk impregnasi, larutan penampak noda serium sulfat [Ce $\left.\left(\mathrm{SO}_{4}\right)_{2}\right] 1,5 \%$ dalam $\mathrm{H}_{2} \mathrm{SO}_{4} 2 \mathrm{~N}, \mathrm{KBr}$ untuk spektrometri infra red (IR), pelarut teknis maupun pro analis is seperti nheksan $\left(\mathrm{C}_{6} \mathrm{H}_{12}\right)$, diklorometana $\left(\mathrm{CH}_{2} \mathrm{Cl}_{2}\right)$, etil asetat (EtOAc), metanol $(\mathrm{MeOH})$, natrium hidroksida $(\mathrm{NaOH})$, as am klorida $(\mathrm{HCl})$ dan alumunium klorida $\left(\mathrm{AlCl}_{3}\right)$.

\section{B. Uji Pendahuluan}

Sampel sebanyak $1 \mathrm{~g}$ dilakukan maserasi menggunakan empat pelarut yang berbeda tingkat kepolarannya yaitu nheksan, diklorometana, etil asetat dan metanol. Sampel direndam pada masing-masing pelarut selama 1×24 jam. Selanjutnya dilakukan monitoring ekstrak sampel dari masing-masing pelarut dengan menggunakan kromatografi lapis tipis (KLT). Eluen yang digunakan adalah n-heksan, diklorometana, etil asetat dan metanol masing-masing $100 \%$. 


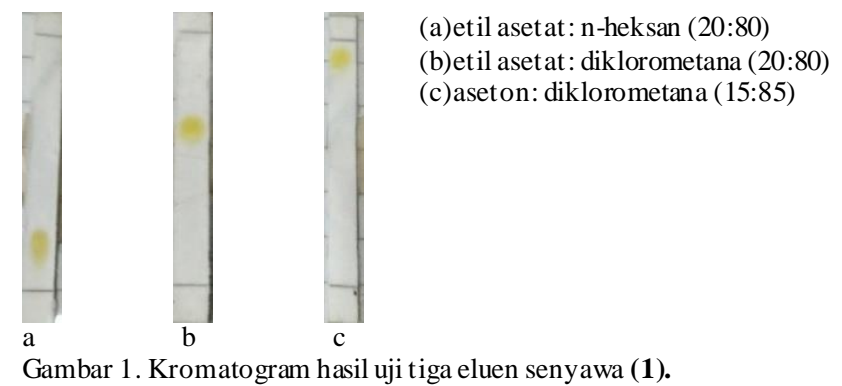

\section{Ekstraksi Sampel}

Sampel kulit batang G. tetrandra sebanyak $3,25 \mathrm{~kg}$ diekstraksi secara maserasi menggunakan pelarut diklorometana selama $3 \times 24$ jam.

\section{Fraksinasi Senyawa}

Terdapat beberapa langkah untuk melakukan fraksinasi ekstrak diklorometana pekat kulit batang $G$. tetrandra. Langkah pertama yakni fraksinasi menggunakan metode kromatografi cair vakum (KCV). Pada awal proses KCV digunakan eluen $100 \%$ n-heksan dilanjutkan dengan eluen diklorometana: n-heksan mulai dari perbandingan (10:90; 25:75 dan 60:40) lalu dinaikkan kepolaran eluen menggunakan etil asetat: n-heksan yang dimulai dari perbandingan (15:85 dan 35:85). Selanjutnya digunakan eluen $100 \%$ etil asetat dan diakhiri dengan $100 \%$ metanol. Proses selanjutnya dimonitoring menggunakan KLT namun hanya vial yang bernomor ganjil yang diuji. Eluen yang digunakan adalah etil asetat: n-heksan (20:80) lalu dilihat dibawah sinar UV kemudian disemprot menggunakan cerium sulfat sebagai penampak noda. Profil kromatogram yang memiliki Rf dan noda yang mirip maka akan dikelompokkan lagi. Hasil KCV didapatkan 8 fraksi yaitu fraksi A $(0,22 \mathrm{~g}), \mathrm{B}(2,69 \mathrm{~g}), \mathrm{C}(11,10 \mathrm{~g}), \mathrm{D}(21,64 \mathrm{~g}), \mathrm{E}$ $(48,92 \mathrm{~g}), \mathrm{F}(28,03 \mathrm{~g}), \mathrm{G}(8,75 \mathrm{~g})$ dan $\mathrm{H}(0,23 \mathrm{~g})$.

Berikutnya fraksi $\mathrm{F}$ difraksinasi menggunakan sephadex dengan eluen metanol: diklorometana (1:1). Selanjutnya dimonitoring menggunakan KLT dengan eluen metanol: diklorometana (2:98). Didapatkan 3 subfraksi yaitu FA (7310 mg), FB (9660 mg) dan FC (9110 mg).

Subfraksi FB difraksinasi menggunakan metode KCV. Eluen awal yang digunakan adalah etil asetat: n-heksan. Persentase perbandingan eluen dinaikkan kepolarannya (5\%, $10 \%, 15 \%, 20 \%$ dan $50 \%$ ), lalu digelontor dengan $100 \%$ etil asetat dan $100 \%$ metanol. Hasil fraksinasi dimonitoring menggunakan KLT. Profil kromatogram yang memiliki Rf yang sama dikelompokkan lagi sehingga didapat 2 subfraksi yaitu J (2790 mg) dan K (4510 mg).

Subfraksi J difraksinasi menggunakan kromatotron. Eluen yang digunakan aseton: n-heksan (15:85). Dimonitoring menggunakan KLT, lalu profil kromatogram yang sama digabung menjadi JC (1810 mg). Fraksi JC dipisahkan menggunakan sephadex. Hasil fraksinasi dimonitoring menggunakan KLT dengan eluen etil asetat: nheksan (20:80). Profil kromatogram JC11 (34 mg) menunjukkan noda tunggal sehingga proses selanjutnya dilakukan uji kemurnian sehingga disebut senyawa (1).

Subfraksi FC difraksinasi menggunakan kromatotron. Eluen yang digunakan adalah etil asetat: n-heksan (20:80). Dimonitoring menggunakan KLT lalu profil kromatogram yang sama digabungkan sehingga didapatkan subfraksi DA (21 mg), DB (4211 mg), DC (3142 mg), DD (136 mg). Subfraksi DD dipisahkan menggunakan sephadex lalu dimonitoring menggunakan KLT dengan eluen etil asetat:n-

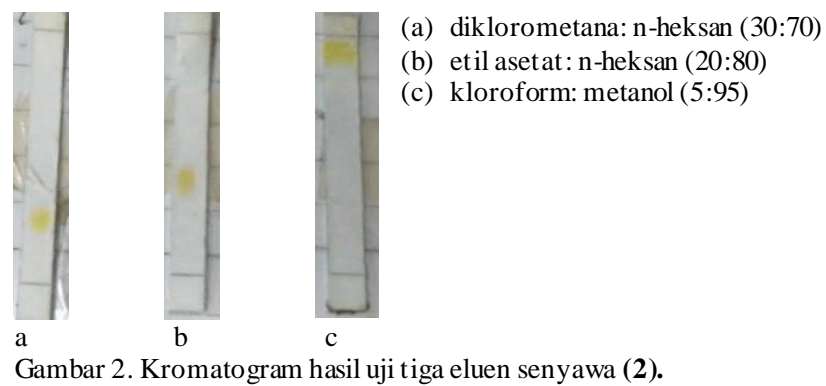

heksan (10:90). Profil kromatogram DD17 (24 mg) menunjukkan noda tunggal dan dilakukan uji kemurnian. Senyawa ini disebut senyawa (2).

\section{E. Uji Kemurnian}

Uji kemurnian yang pertama yaitu dengan uji tiga eluen. Proses uji tiga eluen pada senyawa (1) menggunakan campuran eluen yaitu etil asetat: n-heksan (20:80), etil asetat: diklorometana (20:80) dan aseton: diklorometana (15:85). Pada senyawa (2) menggunakan campuran diklorometana: n-heksan (30:70), etil asetat: n-heksan (20:80) dan kloroform: metanol (5:95)

Uji kemurnian yang kedua yaitu uji titik leleh. Titik leleh sampel yang telah murni diukur dengan meletakkan padatan sampel pada plat titik leleh Fisher John. Suhu dinaikkan secara bertahap sehingga titik leleh diperoleh saat padatan mulai meleleh sampai meleleh sempurna dengan rentang suhu $\pm 1{ }^{\circ} \mathrm{C}$. Senyawa (1) mempunyai rentang suhu sebesar $202-203{ }^{\circ} \mathrm{C}$ dan senyawa (2) mempunyai rentang suhu sebesar $154-155{ }^{\circ} \mathrm{C}$.

\section{F. Pengujian dengan spektroskopi}

Spektroskopi UV-Vis diatur pada $\lambda$ 200-600 $\mathrm{nm}$ dan dicatat $\lambda_{\text {maks }}$ yang diserap dalam bentuk spektrum antara $\lambda$ dan absorbansi. Kristal murni diambil $1 \mathrm{mg}$, kemudian dilarutkan ke dalam blanko yaitu $10 \mathrm{~mL}$ metanol p.a. Larutan metanol sampel dimasukkan kedalam kuvet. Selanjutnya sampel dilakukan uji pengukuran panjang gelombang UV, kemudian larutan ditambahkan $\mathrm{NaOH}, 2-3$ tetes $\mathrm{AlCl}_{3}$ serta $\mathrm{HCl}$ secara berurutan sebagai pereaksi geser untuk melihat pergeseran puncak pada spektrum yang diperoleh dan dilakukan uji pengukuran panjang gelombang UV.

Kristal murni diambil $1 \mathrm{mg}$ dan dilarutkan kedalam $\mathrm{KBr}$ dengan cara digerus sampai homogen. Setelah itu campuran dimasukkan kedalam alat pembuat pellet. Pellet diletakkan pada wadah plat kemudian diukur serapannya dengan alat FTIR-8400 Shimadzu dengan tampilan spektrum menunjukkan puncak-puncak yang menunjukkan gugusgugus tertentu.

Kristal murni diambil $\pm 10 \mathrm{mg}$, kemudian dilarutkan dalam $0,5 \mathrm{~mL}$ pelarut bebas proton. Larutan sampel senyawa dimasukkan kedalam tabung injeksi kemudian diletakkan dalam spektrometer NMR Bruker 400 AVANCE.

\section{HASIL DAN PEMBAHASAN}

\section{A. Senyawa 1}

Kristal senyawa (1) dilakukan uji kemurnian dengan cara monitoring menggunakan KLT dengan tiga eluen yang berbeda tingkat kepolarannya. Senyawa (1) diuji KLT menggunakan eluen etil asetat: n-heksan (20:80), etil asetat: diklorometana (20:80), aseton: diklorometana (15:85) (Gambar 1). Selain itu, uji kemurnian juga dilakukan dengan 
Tabel 1

Data pergeseran ${ }^{1} \mathrm{H}$ dan ${ }^{13} \mathrm{C}$ NMR senyawa (1)

\begin{tabular}{|c|c|c|}
\hline \multirow{2}{*}{ Posisi C } & \multicolumn{2}{|c|}{ Senyawa 1} \\
\hline & ${ }^{13} \mathrm{C}-\mathrm{NMR}$ & ${ }^{1} \mathrm{H}-\mathrm{NMR}$ \\
\hline 1 & 165,38 & \\
\hline 2 & 98,82 & $6.04(\mathrm{~d}, J=2.0 \mathrm{~Hz})$ \\
\hline 3 & 164,92 & - \\
\hline 4 & 93,89 & $6.16(\mathrm{~d}, J=2.0 \mathrm{~Hz})$ \\
\hline $4 a$ & 156,31 & - \\
\hline 5 & 102,88 & $6,69(1 \mathrm{H}, \mathrm{s})$ \\
\hline $5 \mathrm{a}$ & 156,31 & - \\
\hline 6 & 157,5 & - \\
\hline 7 & 144,70 & - \\
\hline 8 & 138,38 & - \\
\hline $8 \mathrm{a}$ & 112,13 & - \\
\hline 9 & 182,75 & - \\
\hline $9 \mathrm{a}$ & 103,79 & - \\
\hline 1 , & 27,39 & $3.97(\mathrm{~d}, J=8.0 \mathrm{~Hz})$ \\
\hline 2 ' & 124,89 & $5,13(1 \mathrm{H}, \mathrm{t}, \mathrm{J}=8,0 \mathrm{~Hz})$ \\
\hline 3 , & 135,23 & - \\
\hline $4^{\prime}$ & 40,54 & $1,88(4 \mathrm{H}, \mathrm{m})$ \\
\hline 5 , & 26,87 & $1,88(4 \mathrm{H}, \mathrm{m})$ \\
\hline 6 ' & 125,89 & $4,89(1 \mathrm{H}, \mathrm{t}, J=6,3 \mathrm{~Hz})$ \\
\hline $7^{\prime}$ & 131,64 & - \\
\hline 8 & 25,83 & $1.37(3 \mathrm{H}, \mathrm{s})$. \\
\hline 9 ' & 17,77 & $1.41(3 \mathrm{H}, \mathrm{s})$ \\
\hline $10^{\prime}$ & 16,67 & $1.68(3 \mathrm{H}, \mathrm{s})$ \\
\hline 7-OMe & 61,50 & $3,65(3 \mathrm{H}, \mathrm{s})$ \\
\hline $1-\mathrm{OH}$ & & $13.34(1 \mathrm{H}, \mathrm{s})$ \\
\hline
\end{tabular}

uji titik leleh menggunakan alat titik leleh Fisher John. Senyawa (1) memiliki titik leleh dengan rentang suhu 202$203{ }^{\circ} \mathrm{C}$.

Setelah itu dilakukan uji spektroskopi UV pada $\lambda$ 200-600 $\mathrm{nm}$ ditambah dengan pereaksi geser $\mathrm{NaOH}, \mathrm{AlCl}_{3}$ dan $\mathrm{HCl}$, uji spektroskopi IR dan uji spektroskopi ${ }^{1} \mathrm{H}$ dan ${ }^{13} \mathrm{C}$ NMR

Dari hasil spektroskopi UV senyawa (1) didapatkan puncak serapan pita I pada $\lambda_{\text {maks }} 345$ dan $307 \mathrm{~nm}$ pita II pada $\lambda_{\text {maks }} 241 \mathrm{~nm}$ yang dapat dilihat pada. Pada puncak serapan pita I menunjukan adanya eksitasi elektron $n \rightarrow \pi^{*}$ yang dapat terjadi pada gugus heteroatomyang terkonjugasi pada ikatan rangkap atau pada cincin aromatik $(-\mathrm{C}=\mathrm{C}-\mathrm{C}=\mathrm{O})$, sedangkan puncak serapan pada pita II menunjukan adanya eksitasi elektron $\pi \rightarrow \pi^{*}$ yang dapat terjadi pada ikatan rangkap yang terkonjugasi pada sistem aromatik $(=\mathrm{C}-\mathrm{C}=\mathrm{C}-\mathrm{C})$. Dari hasil ini, struktur senyawa (1) dapat disarankan memiliki kerangka dasar santon.

Pengukuran spektroskopi UV selanjutnya dilakukan dengan penambahan pereaksi geser $\mathrm{NaOH}$. Setelah penambahan $\mathrm{NaOH}$ dapat terlihat adanya pergeseran batokromik pita I dari $\lambda_{\text {maks }} 345$ ke 362 nm. Adanya pergeseran ini menunjukan terdapat gugus hidroksi $(-\mathrm{OH})$ yang tersubstitusi pada posisi para terhadap gugus karbonil yang mengakibatkan terjadinya kesetimbangan keto-enol. Selain penambahan pereaksi geser $\mathrm{NaOH}$, juga dilakukan penambahan $\mathrm{AlCl}_{3}$ dan $\mathrm{HCl}$ untuk mengetahui keberadaan gugus hidoksi terkhelat dengan karbonil dan gugus orto hidroksi. Dari hasil penambahan $\mathrm{AlCl}_{3}$ didapatkan adanya pergeseran batokromik puncak serapan pita I dari $\lambda_{\text {maks }} 344$ ke $394 \mathrm{~nm}$ dan $307 \mathrm{ke} 335 \mathrm{~nm}$ serta pergeseran batokromik
Tabel 2.

Data pergeseran ${ }^{1} \mathrm{H}$ dan ${ }^{13} \mathrm{C}$ NMR senyawa (2)

\begin{tabular}{|c|c|c|}
\hline \multirow{2}{*}{ Posisi C } & \multicolumn{2}{|c|}{ Senyawa 2} \\
\hline & ${ }^{13} \mathrm{C}-\mathrm{NMR}$ & ${ }^{1} \mathrm{H}-\mathrm{NMR}$ \\
\hline 1 & 161,75 & \\
\hline 2 & 98,35 & $6,24(\mathrm{~s}, 1 \mathrm{H})$ \\
\hline 3 & 161,09 & \\
\hline 4 & 104,16 & \\
\hline $4 a$ & 153,96 & \\
\hline 5 & 101,70 & $6,87(\mathrm{~s}, 1 \mathrm{H})$ \\
\hline $5 a$ & 154,73 & \\
\hline 6 & 155,96 & \\
\hline 7 & 142,89 & \\
\hline 8 & 137,31 & \\
\hline $8 a$ & 112,21 & \\
\hline 9 & 182,43 & \\
\hline $9 \mathrm{a}$ & 104,16 & \\
\hline 1 ' & 21,70 & $3,51(\mathrm{~d}, J=8 \mathrm{~Hz}, 2 \mathrm{H})$ \\
\hline $2^{\prime}$ & 121,64 & $5,27(\mathrm{t}, J=8 \mathrm{~Hz}, 1 \mathrm{H})$ \\
\hline 3 , & 139,06 & - \\
\hline 4 ' & 39,84 & $2,11-2,03(\mathrm{~m})$ \\
\hline 5 , & 26,63 & $2,03-1,96(\mathrm{~m})$ \\
\hline $6^{\prime}$ & 124,43 & $5,02(\mathrm{t}, J=8 \mathrm{~Hz}, 1 \mathrm{H})$ \\
\hline 7 ' & 131,27 & - \\
\hline $8^{\prime}$ & 17,65 & $1,54(\mathrm{~s}, 3 \mathrm{H}))$ \\
\hline 9' & 25,95 & $1,60(\mathrm{~s}, 3 \mathrm{H}$ \\
\hline 10 ' & 16,48 & $1,82(\mathrm{~s}, 3 \mathrm{H})$ \\
\hline $1 "$ & 26,55 & $4,09(\mathrm{~d}, \mathrm{~J}=8 \mathrm{~Hz}, 2 \mathrm{H})$ \\
\hline $2 "$ & 123,7 & $5,27(\mathrm{t}, \mathrm{J}=8 \mathrm{~Hz}, \mathrm{IH})$ \\
\hline $3 ”$ & 135,81 & - \\
\hline $4 "$ & 17,95 & $1,87(\mathrm{~s}, 3 \mathrm{H})$ \\
\hline $5 "$ & 25,60 & $1,74(\mathrm{~s}, 3 \mathrm{H})$ \\
\hline $1-\mathrm{OH}$ & & $13,41(\mathrm{~s})$ \\
\hline $7-\mathrm{OCH}_{3}$ & 62,08 & $3,80(\mathrm{~s}, 3 \mathrm{H})$ \\
\hline
\end{tabular}

pada pita II dari $\lambda_{\text {maks }} 241$ ke 262 nm. Pergeseran ini menunjukan bahwa senyawa (1) tersubstitusi dengan hidroksi $(-\mathrm{OH})$ terkhelat dengan karbonil $(\mathrm{C}=\mathrm{O})$. Namun penambahan pereaksi geser $\mathrm{HCl}$ tidak menyebabkan pergeseran pada pita I maupun pita II yang menunjukan tidak terdapat gugus dihidroksi berposisiorto.

Dugaan adanya gugus hidroksi yang terkhelat dengan karbonil pada spektroskopi UV diperkuat dengan spektroskopi IR, dimana muncul puncak pada bilangan gelombang $3429,55 \mathrm{~cm}^{-1}$ yang merupakan puncak khas untuk gugus hidorksi $(-\mathrm{OH})$ bebas, pada $1643,41 \mathrm{~cm}^{-1}$ yang merupakan puncak khas untuk gugus karbonil $(\mathrm{C}=\mathrm{O})$ yang terkhelat dengan gugus hidroksi dan pada $1298,14 \mathrm{~cm}^{-1}$ yang menunjukan puncak khas untuk gugus (C-O). Selain itu juga muncul puncak-puncak lain pada spektroskopi IR, diantaranya pada $2966,62 \mathrm{~cm}^{-1}, 2922,25 \mathrm{~cm}^{-1}$ dan 2852,81 $\mathrm{cm}^{-1}$ yang menunjukan adanya gugus metil $\left(\mathrm{C}-\mathrm{H} \mathrm{sp}^{3}\right)$ yang dapat berasal dari gugus metoksi maupun prenil/geranil. Kemudian puncak pada 1512,24 - 1433,16 $\mathrm{cm}^{-1}$ menunjukan adanya ikatan rangkap dalam sistem aromatik.

Hasil dugaan sementara struktur senyawa (1) berdasarkan spektroskopi UV dan IR bahwa senyawa (1) memiliki gugus hidroksi terkhelat dengan karbonil diperkuat dengan spektroskopi ${ }^{1} \mathrm{H}-\mathrm{NMR}$, dimana muncul puncak pada pergeseran proton $\delta_{\mathrm{H}} 13,34 \quad(\mathrm{~s}, 1 \mathrm{H})$ yang merupakan pergeseran khas untuk proton hidroksi yang terkhelat dengan karbonil pada senyawa santon. Adanya gugus karbonil ini juga dapat terlihat dari munculnya puncak pergeseran karbon $\delta_{\mathrm{C}} 182,75$ pada ${ }^{13} \mathrm{C}-\mathrm{NMR}$.

Pada ${ }^{1} \mathrm{H}-\mathrm{NMR}$ munculnya puncak pada $\delta_{\mathrm{H}} 6,04(\mathrm{~d}, J=2$ $\mathrm{Hz})$ dan $6,16(\mathrm{~d}, J=2 \mathrm{~Hz})$ menunjukan adanya dua proton aromatik yang berposisi meta. Kemudian juga terdapat pergeseran yang khas untuk proton aromatik terisolasi pada $\delta_{\mathrm{H}} 6,69(1 \mathrm{H}, \mathrm{s})$. Selain itu, keberadaan proton metoksi ditunjukan oleh $\delta_{\mathrm{H}} 3,65(\mathrm{~s}, 3 \mathrm{H})$ dan diperkuat dengan 
munculnya pergeseran karbon pada $\delta_{\mathrm{C}} 61,50$. Selanjutnya adanya kelompok pergeseran proton pada $\delta_{\mathrm{H}} 3.97(\mathrm{~d}, J=8.0$ $\mathrm{Hz})$ yang menunjukan proton metilen, $5,13(1 \mathrm{H}, \mathrm{t}, \mathrm{J}=8,0$ $\mathrm{Hz})$ dan $4,89(1 \mathrm{H}, \mathrm{t}, J=6,3 \mathrm{~Hz})$ yang merupakan proton metin, $1,88(4 \mathrm{H}, \mathrm{m})$ serta tiga ptoton metil pada $1.37(3 \mathrm{H}, \mathrm{s})$, $1.41(3 \mathrm{H}, \mathrm{s})$ dan $1.68(3 \mathrm{H}, \mathrm{s})$ mengindikasikan adanya gugus geranil pada senyawa. Pergeseran yang umum untuk proton metilen yang khas untuk prenil/geranil adalah pada $\delta_{\mathrm{H}} 3,2$ 3,6 ppm, sedangkan sinyal proton metilen pada senyawa (1) ini berada pada pergeseran $\delta_{\mathrm{H}} 3,97 \mathrm{ppm}$. Kemunculan pergeseran yang lebih downfield ini dapat dikarenakan oleh adanya tetangga karbonil. Sehingga terdapat kemungkinan gugus geranil tersubstitusipada posisiC1 atau C2.

Kemudian untuk mengetahui posisi gugus metoksi dan proton aromtik serta untuk menguatkan dugaan sementara struktur senyawa (1), dilakukan perbandingan data ${ }^{13} \mathrm{C}$ NMR dan ${ }^{1} \mathrm{H}-\mathrm{NMR}$ dengan senyawa-senyawa santon yang pernah ditemukan sebelumnya (Tabel 1).

Dari hasil perbandingan senyawa (1) dengan rubrasanton, terlihat pada data-data pergesern proton dan karbon memiliki kemiripan. Sehingga didapatkan struktur senyawa (1) merupakan 1,3,6-trihidroksi-7-metoksi-8-(3,7-dimetil2,6-oktadienil) santon. Maka struktur senyawa (1) adalah:

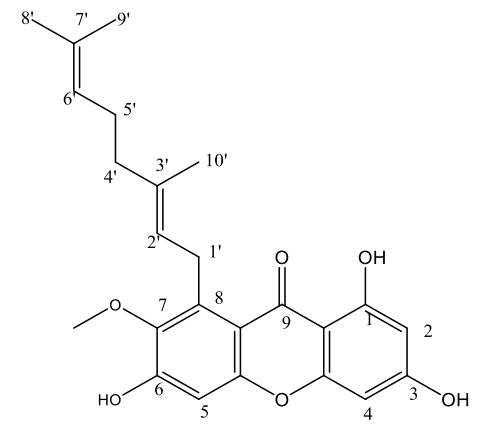

\section{B. Senyawa 2}

Kristal senyawa (2) dilakukan uji kemurnian dengan cara monitoring menggunakan KLT dengan tiga eluen yang berbeda tingkat kepolarannya. Senyawa (2) diuji KLT menggunakan eluen diklorometana: n-heksan (30:70), etil asetat: n-heksan (20:80), kloroform: metanol (5:95) (Gambar 2). Selain itu, uji kemurnian juga dilakukan dengan uji titik leleh menggunakan alat titik leleh Fisher John. Senyawa (2) memiliki titik leleh dengan rentang suhu 154$155^{\circ} \mathrm{C}$.

Dari hasil spektrofotometer UV senyawa (2) dengan pelarut $\mathrm{MeOH}$ didapatkan puncak serapan pita I pada $\lambda_{\text {maks }}$ 358 dan $315 \mathrm{~nm}$ dan pita II pada $\lambda_{\text {maks }} 261$ dan $243 \mathrm{~nm}$ yang dapat dilihat pada. Puncak serapan pita I mengindikasikan adanya eksitasi elektron $n \rightarrow \pi^{*}$ yang dapat terjadi pada gugus heteroatom yang terkonjugasi pada ikatan rangkap atau pada cincin aromatik $(-\mathrm{C}=\mathrm{C}-\mathrm{C}=\mathrm{O})$. Puncak serapan pada pita II menunjukan adanya eksitasi elektron $\pi \rightarrow \pi^{*}$ yang dapat terjadi pada ikatang rangkap yang terkonjugasi pada sistem aromatik (=C-C=C-C). Dari hasil ini struktur senyawa (2) dapat disarankan memiliki kerangka dasar santon.

Kemudian pengukuran spektroskopi UV dilanjutkan dengan penambahan pereaksi geser $\mathrm{NaOH}$. Pada penambahan $\mathrm{NaOH}$ dapat terlihat adanya pergeseran batokromik pita I dari $\lambda_{\text {maks }} 358$ ke $373 \mathrm{~nm}$ serta $\lambda_{\text {maks }} 315 \mathrm{ke}$ $360 \mathrm{~nm}$ yang ditunjukan oleh. Pergeseran ini menunjukan adanya substitusi gugus hidroksi $(-\mathrm{OH})$ pada posisi para terhadap gugus karbonil yang mengakibatkan terjadinya kesetimbangan keto-enol.
Selain penambahan pereaksi geser $\mathrm{NaOH}$ untuk identifikasi struktur senyawa (2), digunakan juga pereaksi geser $\mathrm{AlCl}_{3}$. Setelah ditambahkan $\mathrm{AlCl}_{3}$ terdapat pergeseran pada pita I dari $\lambda_{\text {maks }} 358$ ke $408 \mathrm{~nm}$ dan 315 ke $338 \mathrm{~nm}$ serta pergeseran pada pita II dari $\lambda_{\text {maks }} 261 \mathrm{ke} 279 \mathrm{~nm}$ dan 243 ke $267 \mathrm{~nm}$ yang dapat dilihat pada Gambar 4.19. Pergeseran ini menunjukan adanya substitusi hidroksi $(-\mathrm{OH})$ terkhelat dengan gugus karbonil $(\mathrm{C}=\mathrm{O})$. Hal ini diperkuat dengan pada spektroskopi IR yaitu munculnya puncak pada bilangan gelombang $1656,91 \mathrm{~cm}^{-1}$ yang merupakan puncak khas untuk gugus karbonil $(\mathrm{C}=\mathrm{O})$ yang terkhelat dengan hidroksi (-OH) dan munculnya puncak pada $3392,9 \mathrm{~cm}^{-1}$ yang merupakan puncak khas untuk gugus hidroksi $(-\mathrm{OH})$ bebas, selain itu juga adanya puncak pada $1294 \mathrm{~cm}^{-1}$ yang menunjukan adanya gugus C-O.

Selanjutnya pada penambahan pereaksi geser $\mathrm{HCl}$ tidak terjadi pergeseran yang menunjukan bahwa tidak terdapat substitusi otohidroksi pada senyawa (2). Identifikasi struktur selanjutnya dilakukan dengan spektroskopi IR. Pada spektrum IR adanya ikatan rangkap dalam sistem aromatik ditunjukan oleh munculnya puncak pada 1512,24 -1427,37 $\mathrm{cm}^{-1}$. Kemudian muncul puncak pada bilangan gelombang $2854,74 \mathrm{~cm}^{-1}, \quad 2920,32 \mathrm{~cm}^{-1}$ dan 2968,55 $\mathrm{cm}^{-1}$ yang merupakan puncak khas untuk C-H sp ${ }^{3}$ yang kemungkinan berasal dari gugus prenil/geranil atau metoksi.

Dari hasil spektroskopi UV dan IR dapat disarankan struktur senyawa (2) mengandung kerangka dasar santon yang tersubstitusi $\mathrm{OH}$ pada posisi para terhadap karbonil, $\mathrm{OH}$ yang terkhelat terkhelat dengan karbonil. Selain itu terdapat juga substitusi prenil/geranil atau metoksi. Untuk lebih memperkuat saran struktur senyawa (2) tersebut, dilakukan spektroskopi ${ }^{1} \mathrm{H}-\mathrm{NMR}$ dan ${ }^{13} \mathrm{C}-\mathrm{NMR}$.

Hasil analisa pada spektra ${ }^{1} \mathrm{H}-\mathrm{NMR}$ menujukan 14 sinyal proton seperti tampak pada dan pada spektra ${ }^{13} \mathrm{C}-\mathrm{NMR}$ menunjukan 29 sinyal karbon yang tampak pada. Sinyal pada pergeseran kimia proton $\delta_{\mathrm{H}} 13,41 \mathrm{ppm}$ (s) merupakan sinyal khas untuk gugus hidroksi terkhelat dengan karbonil pada senyawa santon yang diperkuat dengan munculnya pergeseran kimia karbon $\delta_{\mathrm{C}} 182,43 \mathrm{ppm}$. Sinyal proton pada $\delta_{\mathrm{H}} \quad 6,87 \mathrm{ppm}(\mathrm{s}, 1 \mathrm{H})$ dan $6,24 \mathrm{ppm}(\mathrm{s}, 1 \mathrm{H})$ menunjukan pergeseran khas untuk dua proton aromatik. Sinyal proton pada pergeseran $\delta_{\mathrm{H}} 3,80(\mathrm{~s}, 3 \mathrm{H})$ menunjukan adanya proton metoksi pada senyawa (2), hal ini diperkuat dengan munculnya pergeseran karbon pada $\delta_{C}$ 62,08 ppm yang merupakan pergeseran khas untuk karbon metoksi. Kemudian munculnya sinyal proton pada $\delta_{\mathrm{H}} 4,09$ (d, $J=8 \mathrm{~Hz}$, $2 \mathrm{H})$ yang merupakan proton metilen, $\delta_{\mathrm{H}} 5,27(\mathrm{t}, J=8 \mathrm{~Hz}$, $1 \mathrm{H})$ yang merupakan proton metin dan dua proton metil pada $\delta_{\mathrm{H}} 1,87(\mathrm{~s}, 3 \mathrm{H})$ dan $1,74(\mathrm{~s}, 3 \mathrm{H})$ menunjukan adanya gugus prenil. Umumnya proton metilen pada gugus prenil terletak pada pergeseran $\delta_{H}$ 3,2 - 3,6 ppm, namun pada spektra ${ }^{1} \mathrm{H}$ NMR senyawa (2) proton metilen muncul lebih downfield $\left(\delta_{H} 4.0-4,2 \mathrm{ppm}\right)$, hal ini menunjukan bahwa gugus prenil tersebut bertetangga dengan gugus karbonil (Silva, 2005).

Senyawa (2) kemungkinan juga memiliki gugus geranil yang ditunjukan oleh pergeseran proton pada $\delta_{\mathrm{H}} 3,51$ (d, $J$ $=8 \mathrm{~Hz}, 2 \mathrm{H})$ yang merupakan proton metilen, dua proton metin pada $\delta_{\mathrm{H}} 5,27(\mathrm{t}, J=8 \mathrm{~Hz}, 1 \mathrm{H})$ dan $5,02(\mathrm{t}, J=8 \mathrm{~Hz}$, $1 \mathrm{H}), 2,11-2,03(\mathrm{~m}), 2,03-1,96(\mathrm{~m})$, dan tiga proton metil pada $\left.\delta_{\mathrm{H}} 1,54(\mathrm{~s}, 3 \mathrm{H})\right), 1,60(\mathrm{~s}, 3 \mathrm{H})$ dan $1,82(\mathrm{~s}, 3 \mathrm{H})$ (Silva,2005). Dari data ${ }^{1} \mathrm{H}$ NMR tersebut dapat diambil dugaan sementara bahwa senyawa (2) memiliki kerangka santon yang tersubstitusi oleh gugus hidroksi terkhelat 
karbonil, gugus metoksi, gugus hidroksi berposisi para terhadap karbonil, gugus geranil, dua proton aromatik terisolasi dan gugus prenil.

Untuk mengetahui posisi substituen pada senyawa (2), dilakukan perbandingan data ${ }^{13} \mathrm{C}-\mathrm{NMR}$ dan ${ }^{1} \mathrm{H}-\mathrm{NMR}$ pada senyawa santon yang telah ditemukan sebelumnya (Tabel 2).

Dari Tabel 2 dapat dilihat bahwa senyawa (2) dan parvifolisanton $\mathrm{C}$ memiliki pergeseran proton dan karbon yang hampir sama walaupun terdapat perbedaan pergeseran karbon pada C-3 dan C-7'. Namun senyawa (2) dengan pergeseran $\delta_{\mathrm{C}} 161,09$ (C-3) dan 131,27 (C-7') ini memiliki kecocokan dengan senyawa mangostanasanton I dengan pergeseran $\delta_{\mathrm{C}} 161,2$ (C-3) dan 130,4 (C-7'), dimana mangostanasanton I ini memiliki struktur cincin B yang sama dengan parvifolisanton C. Hal ini memperkuat dugaan bahwa senyawa (2) memiliki struktur yang mirip dengan parvifolisanton C. Sehingga dapat disarankan struktur senyawa (2) adalah 1,3,6-trihidroksi-7-metoksi-8-(3-metil-2butenil)-4-(3,7-dimetil-2,6-oktadienil) santon. Maka struktur senyawa (2) adalah:

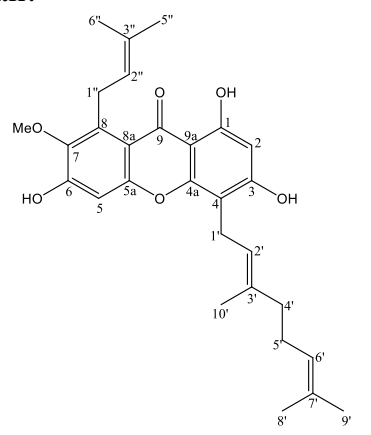

\section{KESIMPULAN}

Telah berhasil diisolasi dua senyawa murni yaitu rubrasanton (1) dan parvifolisanton C (2) dari ekstrak kulit batang $G$. tetrandra Pierre yang berasal dari Taman Nasional Meru Betiri Jember, Jawa Timur. Senyawa 1 dan 2 dapat melengkapi afinitas kimia dari tumbuhan G. tetrandra Pierre sehingga mampu memenuhi jalur biogenesis senyawa santon dari $G$. tetrandra Pierre.

\section{UCAPAN TERIMA KASIH}

Penulis mengucapkan terima kasih kepada Taman Nasional Meru Betiri Jember, kepala laboratorium Kimia Bahan Alam dan Sintes is, departemen Kimia FIA-ITS.

\section{DAFTAR PUSTAKA}

[1] T. Ersam, "Senyawa Kimia Mikromolekul Beberapa T umbuh an Artocarpus Hut an Tropika Sumatera Barat,” Institut Teknologi Bandung, 2011.

[2] K. Heyne, Tumbuhan Berguna Indonesia. Jakarta: Yayasan Sarana Wana Jaya, 1987.

[3] S. Kosela, L. Hu, T. Rachmatia, M. Hanafi, and K. Sim, "Dulxanthones F-H, three new pyranoxanthones from Garcinia dulcis," J, Nat. Prod, vol.63,pp.406-407, 2000.

[4] A. Meilani, "Santon Terprenilasi dan Tersiklisisasi Baru Frak si Non-polar dari Ekstrak n-heksan pada AkarGarcin ia tetran da Pierre," Surabaya, 2006.

[5] A. Riyanto, "Isolasi dan Uji Bakterial Senyawa Sant on dari Kayu Akar Garcinia tetranda Pierre,"Surabaya, 2006.

[6] S. E. Y. Astuti, " $\alpha$-mangostin dan 3-isomangost in dari Fraksi Polar Diklorometana pada Ekstrak Metanol Kulit Bat ang Wadung (Garinia tetranda Pierre)," Surabaya, 2005. 